\title{
Microcalorimetric Study of Extruded Dog Food Containing Probiotic Micro-Organisms
}

\author{
Aram Kazarjan ${ }^{1}$, Natalja Kabanova ${ }^{1,2}$, Raivo Vilu ${ }^{1,2}$ \\ ${ }^{1}$ Tallinn University of Technology, Tallinn, Estonia \\ ${ }^{2}$ Competence Center of Food and Fermentation Technologies (CCFFT), Tallinn, Estonia \\ Email:kazarjan@gmail.com
}

Received August 23, 2012; revised September 23, 2012; accepted October 10, 2012

\begin{abstract}
Extruded dry dog food products claimed to have a probiotic ingredient of Enterococcus faecium (NCIMB10415) in the commercial available formulations under the brand name of ProBiotic LIVE (Bacterfield S.A., Luxembourg) were studied in the present work using a multichannel thermal activity monitor TAM III. Maximum specific growth rate, heat produced during different growth phases, and lag-phase duration were determined. The length of the lag-phase that can be used to determine the time necessary for the probiotic ingredient to restore its activity after consumption of probiotic containing extruded products was also measured. The calorimetric data confirmed the ability of the Enterococcus faecium to grow at the acidic $\mathrm{pH}$ conditions, modeling conditions of gastro-intestinal tract of dogs, and preserve its metabolic activity (viability) at the same level as at the neutral $\mathrm{pH}$. The results obtained indicated that microcalorimetry was a precise and convenient tool for monitoring probiotic activity in complicated solid-state matrices.
\end{abstract}

Keywords: Enterococcus faecium; Probiotic Dog Food; Microcalorimetry

\section{Introduction}

Various attempts have been made to produce extruded feed or food product(s) with stable and viable probiotic bacteria count over the entire shelf-life period of the carrier product [1-3]. However, determination of the number of bacteria, and especially evaluation of their growth and metabolic activity in extruded food and feed products by means of outplating etc. cannot be considered sufficiently precise and convenient.

It has been shown that generation of heat by microbial cultures can be used for on-line monitoring of growth and metabolism of cells [4-10]. Very sensitive measurements of heat flows using microcalorimetry is one of the most attractive techniques for studying and monitoring of the metabolic activity of bacteria in opaque liquid media, and solid matrices [11-13]. It could be successfully applied in the studies of spoilage processes and shelf-life determination of products containing microbes $[8,14-16]$, in fact in all cases where the possibilities of optical and other physical methods are limited due to the non-transparency of media $[17,18]$.

Growth of bacteria in extruded dry dog food products under the brand name of ProBiotic LIVE (Bacterfield S.A., Luxembourg) claimed to contain a probiotic ingredient of Enterococcus faecium (NCIMB10415) were studied in the present work using a multichannel thermal activity monitor TAM III.

\section{Materials and Methods}

\subsection{Samples}

The experiments were performed with dry dog food in the form of extruded kibbles under a brand name of ProBiotic LIVE (Bacterfield S.A., Luxembourg) containing according to the producer viable probiotic bacteria $E n$ terococcus faecium (NCIMB10415) during the entire period of product shelf-life (15 months) at room temperature. The concentration of bacteria as declared on the packaging is $10^{6} \mathrm{cfu}$ per gram of dog food in average. Three commercially available dog food products differentiated by dog age (adult and senior) and by taste (salmon and chicken formulations) were used in the experiments: ProBiotic LIVE Adult Chicken \& Rice (AC), ProBiotic LIVE Adult Salmon \& Rice (AS) and ProBiotic LIVE Senior Chicken \& Rice (SC). All dog food samples used in the experiments were initially received in hermetically closed separate $1.5 \mathrm{~kg}$ bags, with expiry date/lot. nr. 23.11.2012 and used freshly in the middle of the claimed product shelf-life. All the bags were aseptically opened immediately before the experiments. Additionally, dry bacterial concentrate of the same strain of the bacteria as in the dog food (Enterococcus faecium NCIMB10415) provided by Probiotics International Ltd. (UK, Batch No BN 29094, expiry date 11.2013) was studied as a reference sample to dog food formulations. 
The bacterial concentrate contained $10^{10} \mathrm{cfu}$ per gram of the powder according to the producer.

\subsection{Sample Preparation and Experimental Conditions}

Dry dog food kibbles of different types were ground and sifted to fine particles (less than $0.05 \mathrm{~mm}$ ). Afterwards samples were weighed in sterile plastic Falcon tubes. The mass of each sample was approximately $\sim 0.5 \mathrm{~g}$. Samples were aseptically transferred into $3 \mathrm{~mL}$ autoclaved microcalorimetric ampoules. Depending on experimental conditions sterile MilliQ water, adjusted to $\mathrm{pH}=2(\mathrm{dog}$ stomach equivalent $\mathrm{pH}$ [19]), or to $\mathrm{pH}=7$ (neutral value), was added to the ground dry dog food in mass ratio 1:1. $\mathrm{pH}$ was measured with $\mathrm{pH}$ meter S20 Seven Easy Mettler Toledo with calibrated InLab 413 Mettler Toledo electrode. All the solutions were previously sterilized by autoclaving at $121^{\circ} \mathrm{C}$ for $15 \mathrm{~min}$. As a reference, samples of dry non-diluted bacterial concentrate were also analyzed.

In order to determine the initial bacterial concentration in dog food kibbles outplating on PCA (Plate Count Agar, Scharlau, Spain) was carried out for all three dog food formulations and dry bacterial concentrate.

\subsection{Microcalorimetry}

A TAM III (24-channels, TA Instruments, US), a heat conduction multi-channel microcalorimeter was used to monitor the growth of cells in dog food and bacteria concentrate samples. The construction and functioning of the TAM III calorimeter were described earlier by
Wadsö [8]. Microcalorimetric power-time curves were analyzed as described by Kabanova [10]. The calorimetric trials were performed at fixed temperature of incubation at $37^{\circ} \mathrm{C}$ (equivalent of dogs body temperature [20]) using $3 \mathrm{~mL}$ calorimetric ampoules. All the calorimetric experiments were carried out in three parallels and power-time curves obtained were normalized per gram of dog food. Averaged power-time curves of three parallel runs were used for the further analysis.

\section{Results and Discussion}

The averaged power-time curves of growth of Enterococcus faecium (NCIMB10415) in different formulations of dog food in case of dry samples and in moisturized samples at two different $\mathrm{pH}$ values are presented in Figure 1.

The standard deviation of the averaged power-time curves was $0.55 \mu \mathrm{W}$, which was quite low, confirming high reproducibility of the calorimetric method.

Power-time curves were analyzed according to the Kabanova [9] and all numerical values of processed power-time curves are presented in Table 1.

The length of the lag phase was $3.9 \pm 0.72$ hours (in average) at $\mathrm{pH} 7$ (neutral $\mathrm{pH}$ ). The lag phase was prolonged by 1 hour, up to $4.9 \pm 0.2$ hours (in average) at $\mathrm{pH} 2$ (low $\mathrm{pH}$ ), which is the $\mathrm{pH}$ level in the stomach of dogs [13]. Prolongation of the lag-phase at low $\mathrm{pH}$ can be explained by acidic stress effect on the probiotic bacteria.

The average specific maximum growth rate $\left(\mu_{\max }, \mathrm{W} / \mathrm{h}\right)$ of the Enterococcus faecium bacteria was practically the

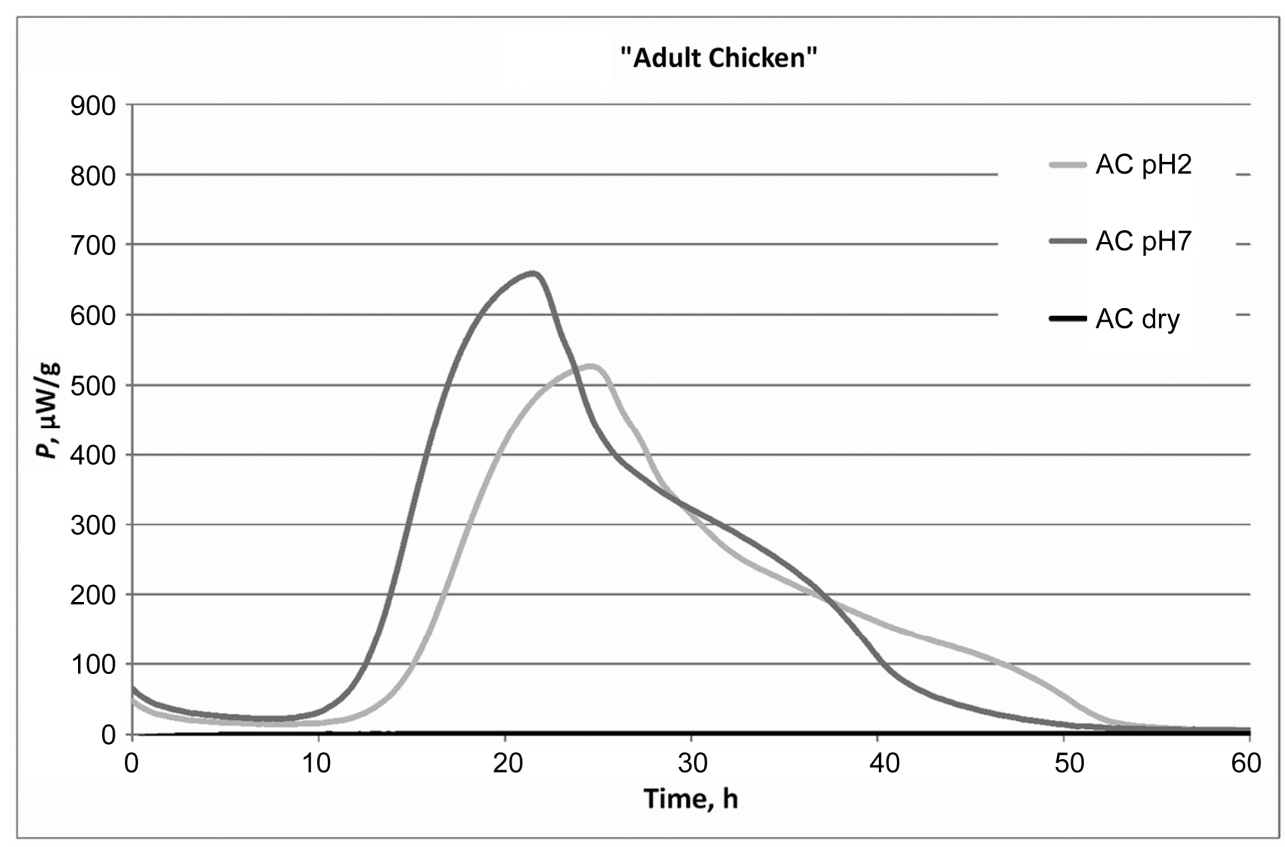

(a) 


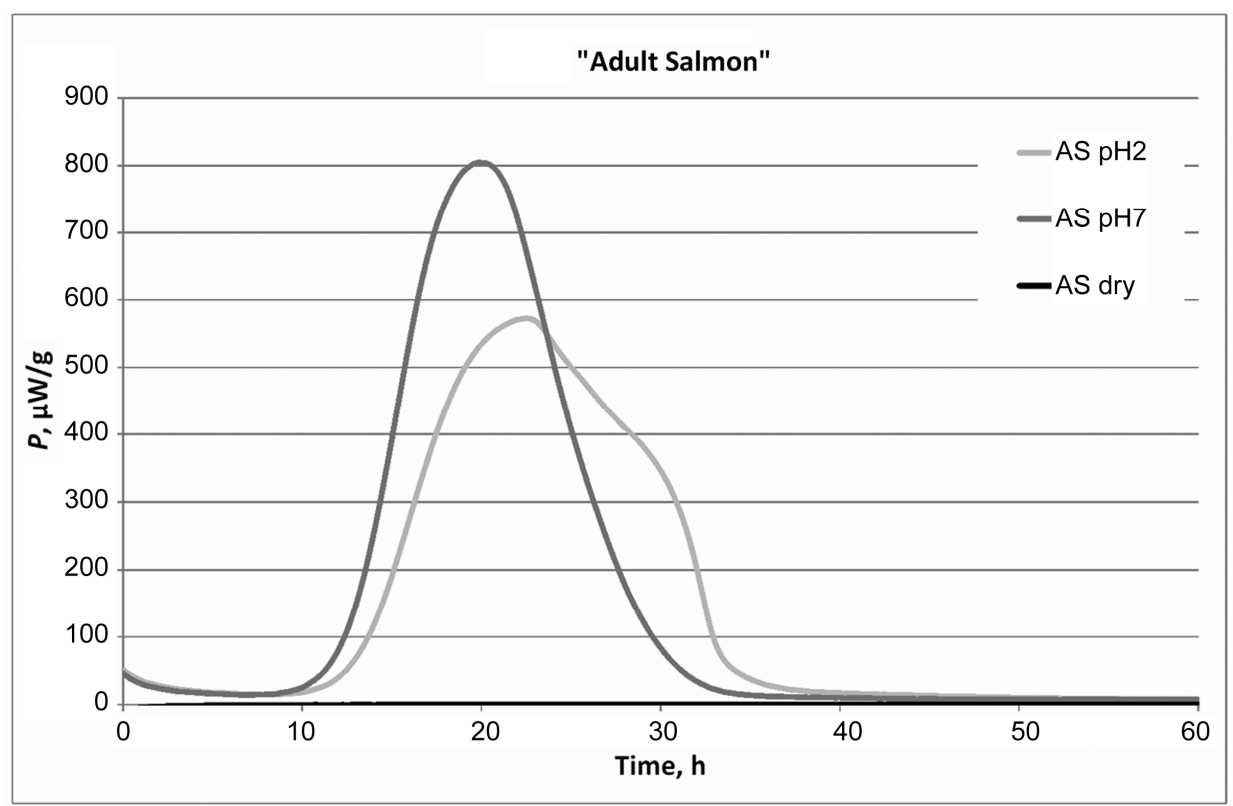

(b)

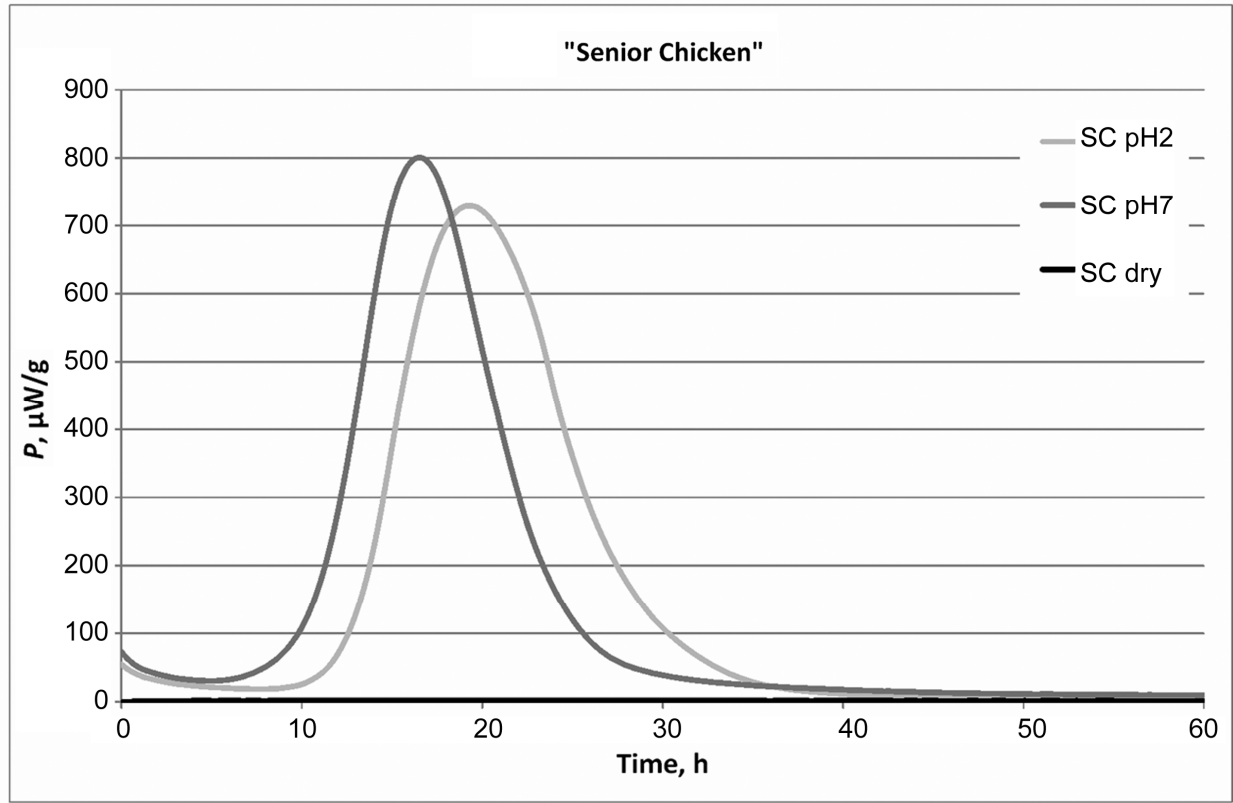

(c)

Figure 1. Power-time curves of growth of probiotic bacteria in three different dog food: dry and moisturized samples (AC, AS and SC) at two different $\mathrm{pH}(\mathrm{pH}=2$ and $\mathrm{pH}=7)$ values.

same at low and neutral $\mathrm{pH}$ levels $(0.5209 \pm 0.0634 \mathrm{~W} / \mathrm{h}$ and $0.5391 \pm 0.0539 \mathrm{~W} / \mathrm{h}$ correspondingly).

The average heat produced during the exponential phase $\left(S_{\text {exp }}, \mathrm{J} / \mathrm{g}\right)$ at neutral $\mathrm{pH}$ was $15.33 \pm 0.90 \mathrm{~J} / \mathrm{g}$ and $13,67 \pm 0.74 \mathrm{~J} / \mathrm{g}$ at acidic $\mathrm{pH}$ condition. Using the $Y_{Q}$ value $2.58 \pm 0.44 \times 10^{-9} \mathrm{~J} / \mathrm{cfu}$ determined by us for $L$. lactis IL1403 [10] the average number of bacteria grown during the exponential growth $\left(N_{\text {exp }}, \mathrm{cfu} / \mathrm{g}-5.93 \times 10^{9}\right.$ $\mathrm{cfu} / \mathrm{g}$ at neutral $\mathrm{pH}$ and $5.29 \times 10^{9} \mathrm{cfu} / \mathrm{g}$ at low $\left.\mathrm{pH}\right)$ was calculated-see Table 1.
The estimates of biomass obtained should be considered reliable, as the values of $Y_{Q}$ have been practically the same in the different papers: $5.53 \times 10^{-8} \mathrm{~J} / \mathrm{cfu}$ for soil samples [21], $4.22 \times 10^{-9} \mathrm{~J} / \mathrm{cfu}$ and $3.4 \times 10^{-8} \mathrm{~J} / \mathrm{cfu}$ for Staphylococcus aureus and E. coli respectively [22].

The total heat produced during the entire period of thermodynamic activity (full length of power-time curves registered, all bacteria growth phases included $S_{\text {tot }}, \mathrm{J} / \mathrm{g}$ ) was also practically the same at both $\mathrm{pH}-\mathrm{s}$ studied. The average total heat produced at neutral $\mathrm{pH}$ was $35.92 \pm$ 
Table 1. Parameters describing bacterial growth of three dog food formulations (AC, AS, SC) at two different $\mathrm{pH}$ (pH $=2$ and $\mathbf{p H}=7$ ) levels obtained from the processed power-time curves: lag phase duration $(\lambda, \mathrm{h})$, maximal specific growth rate $\left(\mu_{\text {max }}, \mathrm{W} / \mathrm{h}\right)$, heat produced during exponential growth phase $\left(S_{\text {exp }}, \mathrm{J} / \mathrm{g}\right)$ and during the total growth $\left(S_{\text {tot }}\right.$ J/g) and the respective numbers of bacteria produced during the both growth phases ( $N_{\exp }, \mathrm{cfu} / \mathrm{g}$ and $N_{\text {tot }}, \mathrm{cfu} / \mathrm{g}$ respectively).

\begin{tabular}{|c|c|c|c|c|c|c|c|c|c|c|c|}
\hline & & $\lambda, \mathrm{h}$ & $\sigma, \mathrm{h}$ & $\mu_{\max }, \mathrm{W} / \mathrm{h}$ & $\sigma, \mathrm{W} / \mathrm{h}$ & $S_{\text {exp }}, \mathrm{J} / \mathrm{g}$ & $\sigma, \mathrm{J} / \mathrm{g}$ & $N_{\text {exp }}, \mathrm{cfu} / \mathrm{g}$ & $S_{\text {tot }}, \mathrm{J} / \mathrm{g}$ & $\sigma, \mathrm{J} / \mathrm{g}$ & $N_{\text {tot }}, \mathrm{cfu} / \mathrm{g}$ \\
\hline \multirow{3}{*}{$\underset{I}{\stackrel{N}{c}}$} & $\mathrm{AC}$ & 4.94 & 0.77 & 0.4547 & 0.05 & 14.28 & 0.86 & $5.53 \mathrm{E}+09$ & 37.09 & 8.58 & $1.44 \mathrm{E}+10$ \\
\hline & AS & 5.08 & 0.49 & 0.5271 & 0.01 & 13.89 & 4.96 & $5.38 \mathrm{E}+09$ & 32.18 & 7.77 & $1.25 \mathrm{E}+10$ \\
\hline & $\mathrm{SC}$ & 4.68 & 0.39 & 0.5809 & 0.00 & 12.85 & 0.92 & $4.97 \mathrm{E}+09$ & 32.37 & 1.74 & $1.25 \mathrm{E}+10$ \\
\hline \multirow{3}{*}{ 全 } & $\mathrm{AC}$ & 3.54 & 0.33 & 0.5039 & 0.03 & 17.24 & 1.13 & $6.67 \mathrm{E}+09$ & 41.62 & 3.78 & $1.61 \mathrm{E}+10$ \\
\hline & AS & 4.73 & 0.09 & 0.6012 & 0.04 & 15.52 & 1.11 & $6.01 \mathrm{E}+09$ & 34.45 & 2.10 & $1.33 \mathrm{E}+10$ \\
\hline & $\mathrm{SC}$ & 3.42 & 0.50 & 0.5123 & 0.17 & 13.21 & 0.47 & $5.11 \mathrm{E}+09$ & 31.68 & 3.40 & $1.23 \mathrm{E}+10$ \\
\hline
\end{tabular}

$0.78 \mathrm{~J} / \mathrm{g}$ and $33.88 \pm 1.23 \mathrm{~J} / \mathrm{g}$ at low $\mathrm{pH}$, which correspond to $1.39 \times 10^{9} \mathrm{cfu} / \mathrm{g}$ and $1.31 \times 10^{9} \mathrm{cfu} / \mathrm{g}$ respectively. The numbers of bacteria grown during the exponential growth phase $\left(N_{\text {exp }}, \mathrm{cfu} / \mathrm{g}\right)$ and bacteria grown during the complete growth $\left(N_{\text {tot }}, \mathrm{cfu} / \mathrm{g}\right)$ achieved the same levels of $10^{9}$ and $10^{10} \mathrm{cfu} / \mathrm{g}$ correspondingly at the two $\mathrm{pH}$ values.

All three formulations of ProBiotic LIVE dog food (AC: Adult Chicken \& Rice, AS: Adult Salmon \& Rice and AS: Senior Chicken \& Rice) enriched with probiotic bacteria of Enterococcus faecium (NCIMB10415) had the same initial bacterial count in average $10^{6} \mathrm{cfu} / \mathrm{g}$ confirmed by outplating of the samples on the PCA presented in Table 2. Average concentration of bacteria in all the three dog food formulations was $2.86 \times 10^{6} \pm 5.31$ $\times 10^{5} \mathrm{cfu} / \mathrm{g}$ according to the results presented in Table 2 . This confirms the claimed by a producer average $E$. faecium load of $10^{6} \mathrm{cfu}$ per gram in the product.

It is known that the low acidic $\mathrm{pH}$ in the stomach of dogs is considered as a barrier for the probiotic bacteria. Ability to preserve the viability during the passage through the stomach acidic barrier is a prerequisite for the further successful colonization of the host intestine by the probiotic bacteria. The Enterococcus faecium bacteria present in the dog food of ProBiotic LIVE formulations were able to show strong metabolic activity at low acidic pH value, which confirmed the fact that Enterococcus faecium can tolerate the passage through the acidic barrier of the dog's stomach and populate the intestine afterwards. The ability of the probiotic bacteria Enterococcus faecium (NCIMB10415), to preserve the activity throughout the passage through the stomach acidic barrier of dogs was also confirmed in the trials of the European Food Safety Authority (EFSA, [23]). Analysis of the power-time curves revealed that the duration of the time needed for the probiotic bacteria to regain their activity in the host organism after consumption, the length of the lag-phase, was about 5 hours (see Table 1). This time is sufficient for the digest flow to pass the acidic barrier of stomachs of dogs.
Table 2. Plate counts of the bacteria on PCA and pH values of different dog food formulations and bacteria concentrate.

\begin{tabular}{cccc}
\hline Sample & $N, \mathrm{cfu} / \mathrm{g}$ & $\sigma, \mathrm{cfu} / \mathrm{g}$ & Bulk pH \\
\hline AC & $2.35 \mathrm{E}+06$ & $2.19 \mathrm{E}+04$ & 5.77 \\
AS & $3.41 \mathrm{E}+06$ & $6.17 \mathrm{E}+04$ & 5.87 \\
SC & $2.82 \mathrm{E}+06$ & $5.14 \mathrm{E}+04$ & 5.94 \\
Bact. concentrate & $2.24 \mathrm{E}+10$ & $3.28 \mathrm{E}+08$ & 5.23 \\
\hline
\end{tabular}

There was no bacterial metabolic activity observed in the case of non-diluted dry dog food samples analyzed, see Figure 1. Also the freeze-dried Enterococcus faecium (NCIMB10415) bacteria powder concentrate (both dry and diluted samples) showed no thermal activity (data not shown).

\section{Conclusions}

The results obtained showed clearly the ability of the probiotic Enterococcus faecim (NCIMB10145) bacteria strain present in the extruded dog food kibbles to preserve its viability and growth characteristics at acidic and neutral $\mathrm{pH}$. This indicated that the extruded kibbles containing E. faecium bacteria are able to tolerate the dog's stomach acidic barrier with further successful colonization of the dog's intestine.

The results obtained showed that calorimetric technique is a prospective and sensitive method for the continuous in-situ monitoring of bacterial activity in such complicated matrices as extruded feed or food products, and for shelf-life determination of probiotic ingredients in the products.

\section{Acknowledgements}

This investigation was financially supported through the grant ETF9192 of Estonian Science Foundation, through the grant SF0140090s08 of Estonian Ministry of Education and Research, and by the European Regional Development Fund project EU29994. 
The authors wish to thank the Probiotics International Ltd. (UK) for providing the sample of the bacteria concentrate and Bacterfield S.A. (Luxembourg) for providing the dog food samples.

\section{REFERENCES}

[1] S. D. Forssten, C. W. Sindelar and A. C. Ouwehand, "Probiotics from an Industrial Perspective," Anaerobe, Vol. 17, No. 6, 2011, pp. 410-413.

doi:10.1016/j.anaerobe.2011.04.014

[2] A. C. Ouwehand, "Recent Advances in Probiotic Research: A Conference Update," Future Microbiology, Vol. 6, No. 9, 2011, pp. 981-984. doi:10.2217/fmb.11.76

[3] W. Kneifel and S. Salminen, "Probiotics and Health Claims," Wiley-Blackwell, London, 2011. doi:10.1002/9781444329384

[4] L. Yi, L. Xi, Q. Songsheng and S. J. Ping, "Microcalorimetric Investigation of the Toxic Action of $\mathrm{Cd} 2+$ on Rhizopus nigricans Growth," Journal of Biochemical and Biophysical Methods, Vol. 45, No. 2, 2000, pp. 231-239. doi:10.1016/S0165-022X(00)00115-9

[5] L. Gustafsson, "Microbiological Calorimetry," Thermochimica Acta, Vol. 193, 1991, pp. 145-171. doi:10.1016/0040-6031(91)80181-H

[6] H. Vandenhove, "Microclaorimetric Characterization of Bacterial Inocula," Advanced Instrumentation, Data Interpretation, and Control of Biotechnological Processes, Vol. 25, 1998, pp.121-158.

[7] I. Lamprecht, "Calorimetry and Thermodynamics of Living Systems," Thermochimica Acta, Vol. 405, No. 1, 2003, pp. 1-13. doi:10.1016/S0040-6031(03)00123-0

[8] L. Wadsö and F. G. Galindo, "Isothermal Calorimetry for Biological Applications in Food Science and Technology," Food Control, Vol. 20, 2009, pp. 956-961. doi:10.1016/j.foodcont.2008.11.008

[9] N. Kabanova, A. Kazarjan, I. Stulova and R. Vilu, "Microcalorimetric Study of Growth of Lactococcus lactis IL1403 at Different Glucose Concentrations in Broth," Thermochimica Acta, Vol. 496, No. 1-2, 2009, pp. 87-92. doi:10.1016/j.tca.2009.07.003

[10] N. Kabanova, I. Stulova and R. Vilu, "Microcalorimetric Study of the Growth of Bacterial Colonies of Lactococcus lactis IL1403 in Agar Gels," Food Microbiology, Vol. 29, No. 1, 2012, pp. 67-79. doi:10.1016/i.fm.2011.08.018

[11] D. A. Mitchell, O. F. von Meien, N. Krieger and F. D. H. Dalsenter, "A Review of Recent Developments in Modeling of Microbial Growth Kinetics and Intraparticle Phenomena in Solid-State Fermentation," Biochemical Engineering Journal, Vol. 17, No. 1, 2004, pp. 15-26. doi:10.1016/S1369-703X(03)00120-7

[12] I. Stulova, N. Kabanova, T. Kriščiunaite, T.-M. Laht and R. Vilu, "The Effect of Milk Heat Treatment on the Growth Characteristics of Lactic Acid Bacteria," Agron- omy Research, Vol. 9, 2011, pp. 473-478.

[13] A. Mihhalevski, I. Sarand, E. Viiard, A. Salumets and T. Paalme, "Growth Characterization of Individual Rye Sourdough Bacteria by Isothermal Microcalorimetry," Journal of Applied Microbiology, Vol. 110, No. 2, 2011, pp. 529540. doi:10.1111/j.1365-2672.2010.04904.x

[14] M. Riva, D. Fessas and A. Schiraldi, "Isothermal Calorimetry Approach to Evaluate Shelf Life of Foods," Thermochimica Acta, Vol. 370, 2001, pp. 73-81. doi:10.1016/S0040-6031(00)00782-6

[15] C. Alklint, L. Wadso and I. Sjoholm, "Accelerated Storage and Isothermal Microcalorimetry as Methods of Predicting Carrot Juice Shelf-Life," Journal of the Science of Food and Agriculture, Vol. 85, No. 2, 2005, pp. 281-285. doi:10.1002/jsfa.1942

[16] U. von Stockar and L. A. M. van der Wieler, "Thermodynamics in Biochemical Engineering," Journal of Biotechnology, Vol. 59, No. 1-2, 1997, pp. 25-37. doi:10.1016/S0168-1656(97)00167-3

[17] M. Antwi, K. Barnaerts, J. F. Van Impe and A. H. Geeraerd, "Modelling the Combined Effects of Structured Food Model System and Lactic Acid on Listeria innocua and Lactococcus lactis Growth in Mono- and Coculture," International Journal of Food Microbiology, Vol. 120, 2007, No. 1-2, pp. 71-84. doi:10.1016/j.ijfoodmicro.2007.04.015

[18] P. D. G. Wilson, T. F. Brocklehurs, S. Arino, D. Thuault, M. Jakobsen, M. Lange, J. Farkas, J. W. T. Wimpenny and J. F. Van Impe, "Modelling Microbial Growth in Structured Foods: Towards a Unified Approach," International Journal of Food Microbiology, Vol. 73, No. 2-3, 2002, pp. 275-289. doi:10.1016/S0168-1605(01)00660-2

[19] M. Akimoto, N. Nagahata, A. Furuya, K. Fukushima, S. Higuchi and T. Suwa, "Gastric pH Profiles of Beagle Dogs and Their Use as an Alternative to Human Testing," European Journal of Pharmaceutics and Biopharmaceutics, Vol. 49, 2000, pp. 99-102. doi:10.1016/S0939-6411(99)00070-3

[20] D. G. Carlson and J. M. Griffin, "Dog Owner's Home Veterinary Handbook," Howell, New York, 1992.

[21] T. Kimura and K. Takahashi, "Calorimetric Studies of Soil Microbes: Quantitative Relation between Heat Evolution during Microbial Degradation of Glucose and Changes in Microbial Activity in Soil," Journal of General Microbiology, Vol. 131, No. 11, 1985, pp. 30833089. doi:10.1099/00221287-131-11-3083

[22] S. Bayne-Jones and H. S. Rhees, "Relationship of Heat Production to Phases of Growth of Bacteria," Journal of Bacteriology, Vol. 17, No. 2, 1929, pp. 123-140.

[23] The European Food Safety Authority, "Opinion of the Scientific Panel on Additives and Products or Substances Used in Animal Feed on the Safety of Product Oralin for Dogs," The European Food Safety Authority Journal, Vol. 51, 2004, pp. 1-6. 